\title{
CFD SIMULATIONS OF HEAT TRANSFER IN INTERNALLY HELICALLY RIBBED TUBES
}

\author{
Karol Majewski*, Sławomir Grądziel \\ Cracow University of Technology, al. Jana Pawla II 37, 31-864 Cracow, Poland
}

\begin{abstract}
Heating surfaces in power boilers are exposed to very high heat flux. For evaporator protection against overheating, internally helically ribbed tubes are used. The intensification of the heat transfer and the maintenance of the thin water layer in the intercostal space, using ribbed tubes, enables better protection of the power boiler evaporator than smooth pipes. Extended inner surface changes flow and thermal conditions by influencing the linear pressure drop and heat transfer coefficient. This paper presents equations that are used to determine the heat transfer coefficient. The results of total heat transfer, obtained from CFD simulations, for two types of internally ribbed and plain tubes are also presented.
\end{abstract}

Keywords: heat transfer coefficient, helically internally ribbed tubes, power boilers

\section{INTRODUCTION}

Nowadays efficiency improvement and development of new computational methods for modelling phenomena occurring in power boilers are important scientific challenges. In order to extend the lifetime of boilers, many studies have been performed concerning monitoring stress in criterion elements of boilers, such as drums (Grądziel S., 2011; Węglowski et al., 2014). Another problem is increasing the flexibility of power boilers, which can be achieved by fast start-up processes. The reasons for which boilers flexibility is very important were described by Pilarczyk and Cisek (2014). The increase of boiler flexibility can be achieved by the optimum heating and cooling rates for thickwalled boiler components (Dzierwa and Taler, 2015; Dzierwa et al., 2014).

CFD modelling of fluid and thermal flow phenomena in power boilers can be generally divided into three categories: combustion and flue gas flow, the flow of steam in superheaters and modelling flow with boiling in waterwalls. Combustion and flow of flue gases with fly ash and deposit formation on superheaters outer surface have been recently presented in many studies, e.g. by Modliński (2014), Nowak-Woźny et al. (2013) and Wacławiak and Kalisz (2014). Other studies include numerical modelling and mathematical models that describe fluid and thermal flow of steam and flue gas through multi-pass exchangers, such as superheaters. Taler et al. (2014) and Trojan et al. (2014) presented methods of modelling superheaters, which include the effect of deposits of ash. Another very important issue is the control of steam temperature. Numerical modelling of this process was presented by Zima (2006). The last category of phenomena refers to heat transfer in waterwalls. These issues are very complicated because surfaces are exposed to large heat fluxes. Measurements of heat flux in combustion chambers are very difficult. Taler et al. (2009) presented one of the methods. A large amount of heat is needed to water evaporation. Papers about evaporation and simplified process modelling using Author's calculation code were presented by Ocłoń et al. (2013) and Ocłoń et al. 
(2014). Phenomena described above have to be under control to provide safety and efficiency of power boiler operation.

Some boilers operate in critical and supercritical parameters. When these units work in slip parameters, boiling crisis may occur. In this state, wall temperature of waterwalls reaches very high values. This in turn, can cause destruction of the pressure components. To protect tubes against thermal damage, in Benson low mass flux design, rifled tubes are used. Their greatest advantage, in relation to plain tubes, is the ability to move the boiling crisis to the steam quality $\mathrm{x} \approx 0.9$ (Taler, 2011).

By adding spiral ribs, internal geometry enhancement of the tubes changes flow and thermal conditions. Fluid motion evolves into swirl flow in the entire length of the tube, and even at low Reynolds numbers turbulent flow occurs. The heating process is intensified, which leads to maintaining safe operating temperature of tubes. At the same time, increasing the surface area by adding internal ribs, increases losses due to friction for the same mass flow rate as smooth tubes. Due to this, internally helically ribbed tubes are used especially in CFB (Circulating Fluidised Bed) power boilers with Benson evaporator. These kinds of boilers can safely work with water mass flux $600-1200 \mathrm{~kg} /\left(\mathrm{m}^{2} \cdot \mathrm{s}\right)$ that is lower than in others constructions $\left(1000-2000 \mathrm{~kg} /\left(\mathrm{m}^{2} \cdot \mathrm{s}\right)\right)($ Taler, 2011).

The article presents two examples of rifled tubes and their characteristic dimensions. Comparison of linear pressure drop for calculated with literature-based equations is shown. Equations that describe heat transfer coefficient in rifled tubes are also presented. The main aim of this paper is to present CFD modelling of heat transfer process in rifled tubes and to compare the results with plain tubes. CFD modelling has been done in Ansys Fluent application (ANSYS Inc.).

\section{CHARACTERISTIC DIMENSIONS OF INTERNALLY HELICALLY RIBBED TUBES}

The character of fluid flow and heat transfer process in the case of tubes with internal helical fins depends on geometrical dimensions of ribs. The most important shapes and dimensions that affect fluid and thermal flow, are presented in Fig. 1 (Majewski, 2013).

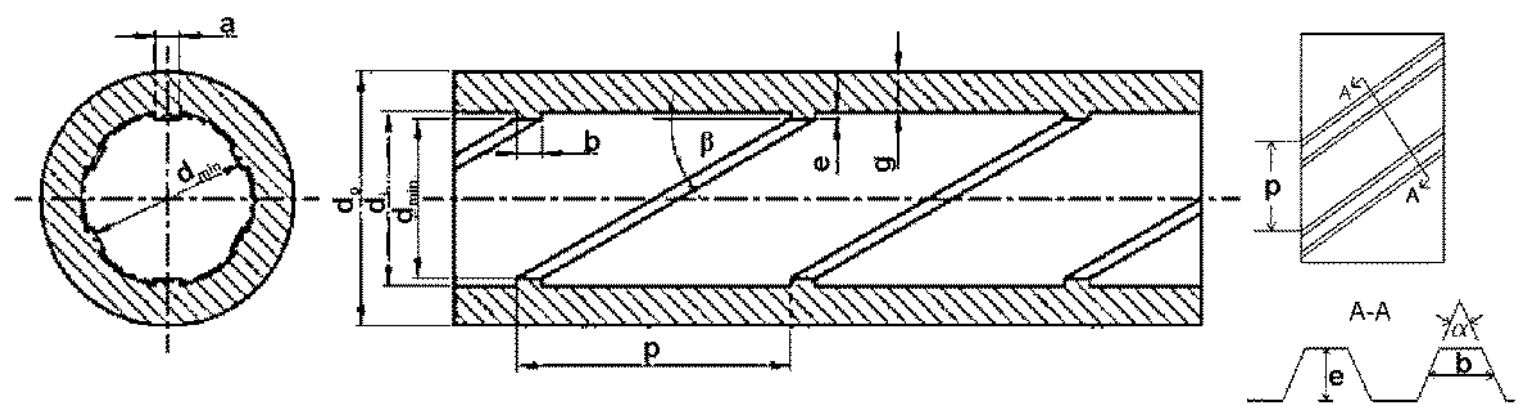

Fig. 1. Characteristic dimensions of rifled tubes

a)

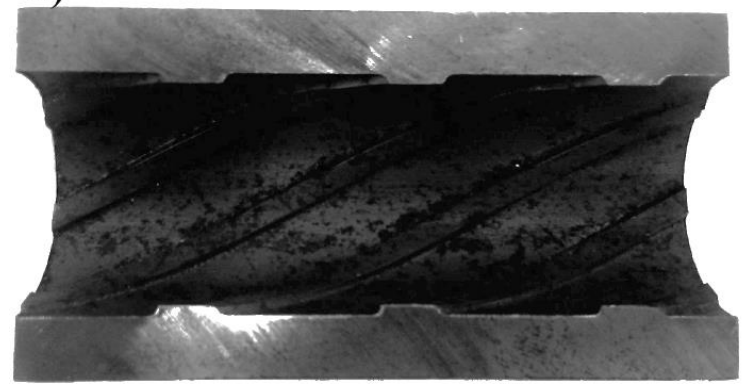

b)

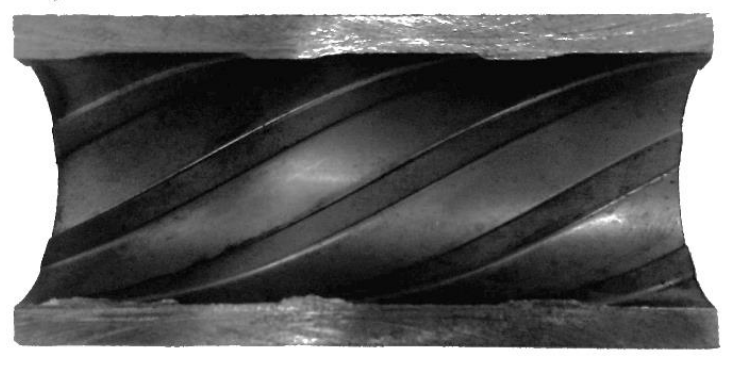

Fig. 2. Examples of internally helically ribbed tubes - longitudinal cross-sections 
Many studies contain analysis of the fluid and thermal flow in rifled tubes (Carnavos, 1980; Pan et al., 2011; Webb et al., 2000; Zdaniuk et al., 2008). It was shown that heat transfer coefficients and linear pressure drop depend on: the internal diameter without ribs $d_{i}$ and with the ribs $d_{\min }$, ribs height $e$, pitch $p$, helix angle $\beta$ of ribs. The number of ribs $N$ and their average width $b$ have a very high impact on that as well. Examples of helically internally ribbed tubes are shown in Fig. 2 and their characteristic dimensions in Table 1. These tubes are used in CFD analysis. For these tubes the CFD analysis is carried out.

Table 1. Characteristic dimensions of presented tubes

\begin{tabular}{|l|c|c|c|}
\hline & Symbol & Tube a & Tube b \\
\hline Internal diameter, $\mathrm{mm}$ & $d_{i}$ & 34.9 & 33.6 \\
\hline Minimal diameter, $\mathrm{mm}$ & $d_{\min }$ & 32.9 & 32.2 \\
\hline Wall thickness, $\mathrm{mm}$ & $g$ & 7.95 & 4.7 \\
\hline Ribs height, mm & $e$ & 1.0 & 0.7 \\
\hline Rib average width, mm & $b$ & 4.5 & 6 \\
\hline Pitch, mm $^{\text {Helix angle, }}{ }^{\circ}$ & $p$ & 30 & 33 \\
\hline Number of ribs & $\beta$ & 30 & 30 \\
\hline
\end{tabular}

\section{LINEAR PRESSURE DROP IN RIFLED TUBES}

Equations that allow the calculations of a linear friction factor coefficient in helically internally ribbed tubes are presented in a study by Majewski (2013). The analysis of friction factors for rifled tubes and the comparison with Blasius equation are presented in Fig. 3. Described tubes vary in inner diameter and the height of the ribs $(1 \mathrm{~mm}$ and $0.7 \mathrm{~mm})$, so the differences in pressure drops are expected. The experimentally developed equation is the Reynolds number function. Additionally, correlations 2 and 3 shown in Fig. 3 are also based on the number of ribs, the ratio of rib height to the internal diameter and the helix angle of the ribs (Webb et al., 2000; Zdaniuk et al., 2008).

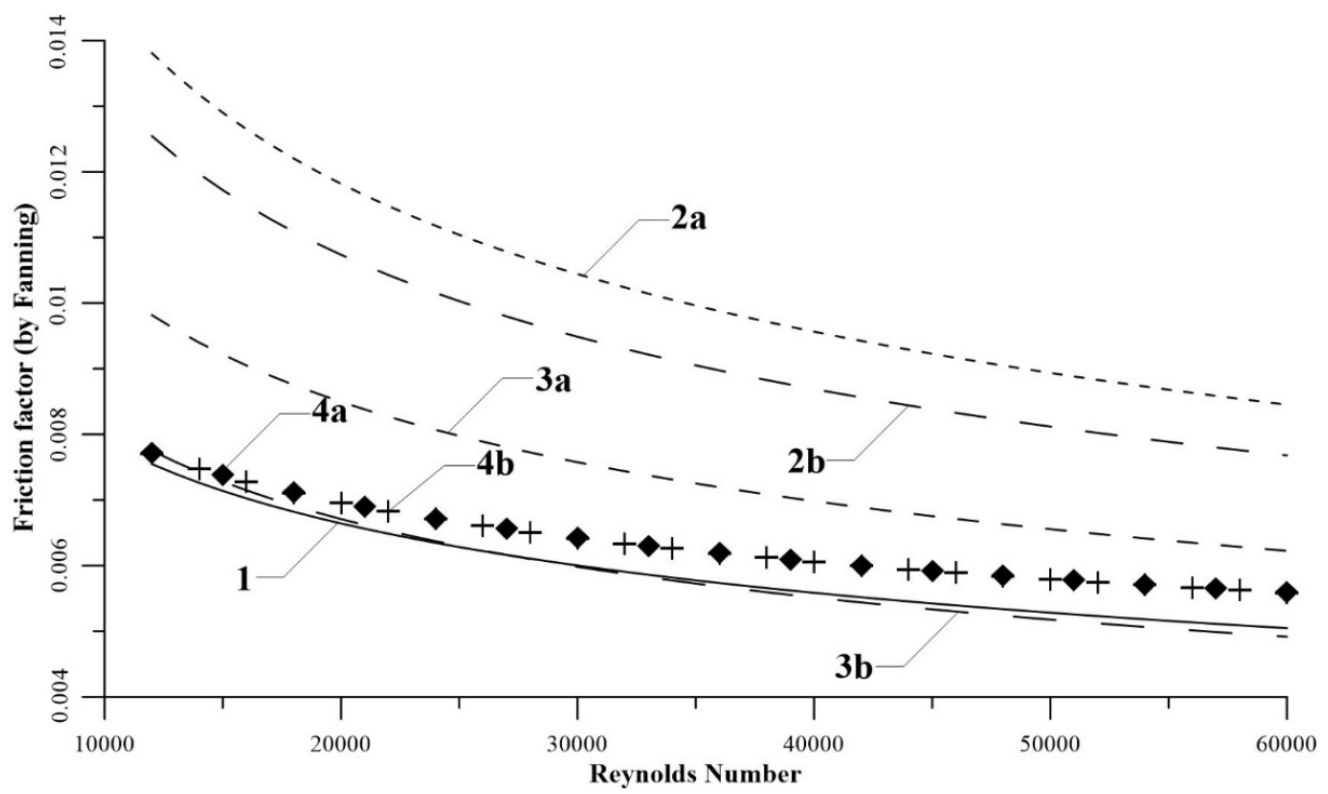

Fig. 3. Comparison of friction factor in presented tubes with smooth tube;

1 - smooth tube; 2 - Zdaniuk et al. (2008); 3 - Webb et al. (2000);4 - Carnavos (1980);

$\mathrm{a}, \mathrm{b}$ - presented tubes (Fig. 2) 
Therefore, there are visible differences in the course of obtained results for tubes $a$ and $b$. Otherwise, the results obtained from Carnavos equation are presented (lines $4 \mathrm{a}$ and $4 \mathrm{~b}$ in Fig. 3). This equation uses the ratio of cross-sectional area of a channel without ribs $A_{n}$ to the channel cross-sectional with ribs $A_{x s}$. The obtained results are very similar because the area ratio $A_{n} / A_{x s}$ for the presented tubes is almost the same. This area difference for both tubes is about $0.13 \%$.

The differences between the various models are due to the fact, that they have been developed based on measurements carried out on tubes with a smaller diameter, different number, helix angle and height of the greater numbers ribs than those on presented examples. Therefore, Webb et al. (2000) and Zdaniuk et al. (2008) developed a friction factor based on a greater number of characteristic dimensions than Carnavos (1980).

\section{HEAT TRANSFER COEFFICIENT IN RIFLED TUBES}

The use of tubes with internal helical fins enhances heat transfer, which, even in high thermal load, helps to maintain safe operating temperature of the tube. This is achieved by several dimensions. The most important influence has the spiral shape of the fins inside the tubes. The geometry of these ribs causes a swirl flow of fluid and increase the turbulence of flow. In this conditions, heat transfer coefficient, related to the smooth tubes, increases.

Determination of heat transfer coefficient $h$ in helically ribbed tubes can be done in several ways. In laboratory scale, the value of heat transfer coefficient can be determined by known heat flux and temperature measurement of the inner wall and the fluid bulk temperature (Pan et al., 2011):

$$
h=\frac{\dot{q}}{T_{w}-T_{b}}
$$

Determination of an average wall temperature becomes problematic. Due to the presence of the ribs, the wall temperature measurements must be conducted at several points and obtained values should be averaged. Pan et al. (2011) and Majewski (2013) presented laboratory stands, which allow to use this method.

According to Zdaniuk et al. (2008) and Webb et al. (2000), the heat transfer coefficient can be determined by the Chilton-Colburne parameter. In this case, the Prandtl and Stanton numbers are used:

$$
j=S t \cdot \operatorname{Pr}^{2 / 3}
$$

Authors show the experimental way of determination of the Chilton-Colburne parameter as a function based on the Reynolds number and characteristic dimensions of rifled tubes. Equation (3) was presented by Webb et al. (2000) and Eq. (4) was presented by Zdaniuk et al. (2008):

$$
\begin{aligned}
& j=0.00933 R e^{-0.181} N^{0.285}\left(\frac{e}{d_{i}}\right)^{0.323} \beta^{0.505} \\
& j=0.029 \operatorname{Re}^{-0.347} N^{0.253}\left(\frac{e}{d_{i}}\right)^{0.0877} \beta^{0.362}
\end{aligned}
$$

In order to determine the heat transfer coefficient the criterion of the Nusselt is also in use:

$$
N u=\frac{l_{c} h}{k}
$$


Equation (5) is difficult to apply for internally helically ribbed tubes. Therefore, to determine heat transfer coefficient, the Nusselt number in rifled and plain tubes can be compared. An example of the method was presented by Jensen and Vlakancic (1999):

$$
\frac{N u}{N u_{p}}=\left(\frac{l_{c s w}}{d_{i}}\right)^{-0.5}\left(\frac{A_{n}}{A_{x s}}\right)^{0.8}[f(\text { geometry })]
$$

The Nusselt number in internally helically ribbed tubes is a function of geometric parameters and specific ratios of geometric factors. Geometry function also depends on the height of the ribs.

\section{CFD MODELLING}

CFD modelling of fluid and thermal flow in rifled tubes is presented in a simplified form in Fig. 4. This case was divided into few parts. The first one refers to preparing geometry. This part of preparation is much more complicated than in smooth tubes, because of the presence of the ribs. As for the meshing process, the model (fluid and solid bodies) has to be divided into 36 sub-bodies. This partitioning allows to prepare a good regular mesh. It also helps to improve the meshing in intercostal and in the zone close to ribs. Examples of the model and the mesh are presented in Fig. 5.

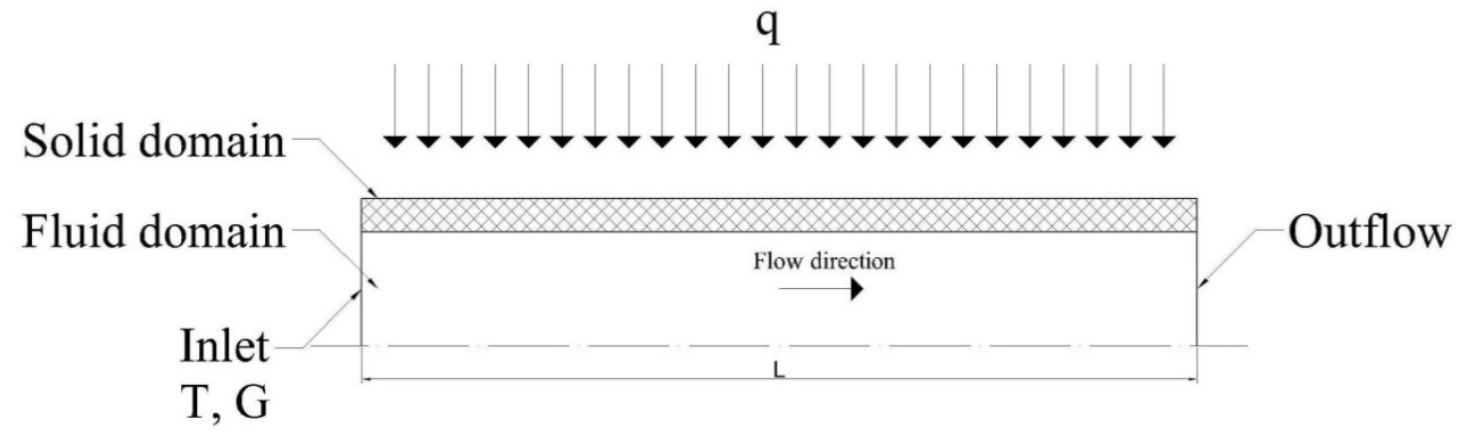

Fig. 4. Simplified model geometry

Mesh has been generated in ANSYS Workbench Meshing module. To prepare the mesh presented in Fig. 5b, the Sweep Method and Edge Sizing on typical edges and bodies were used. In this case, the length of a single element in the Sweep Method has to be taken from a specific range. It has a large influence on the grid quality in skewed elements. The numbers of nodes and cells in compared grids are presented in Table 2 .

Table 2. Number of elements and nodes for mesh in compared cases

\begin{tabular}{|c|c|c|c|c|}
\hline \multirow{2}{*}{ Tube } & \multicolumn{2}{|c|}{ Rifled } & \multicolumn{2}{c|}{ Plain } \\
\cline { 2 - 5 } & Cells & Nodes & Cells & Nodes \\
\hline a & 897147 & 921536 & 303485 & 313960 \\
\hline b & 823440 & 842112 & 244122 & 255176 \\
\hline
\end{tabular}

Next, the generated mesh was loaded to the ANSYS Fluent application. In general settings the steadystate analysis was chosen. The gravitational acceleration effect was also included in the opposite direction to the fluid flow. After defining the main settings, mathematical models connected to the flow, such as energy and turbulence models were chosen. As the turbulence model, the transition SST model was used. This model was selected because it allows to map the phenomena in boundary layers and in the bulk of the fluid. 

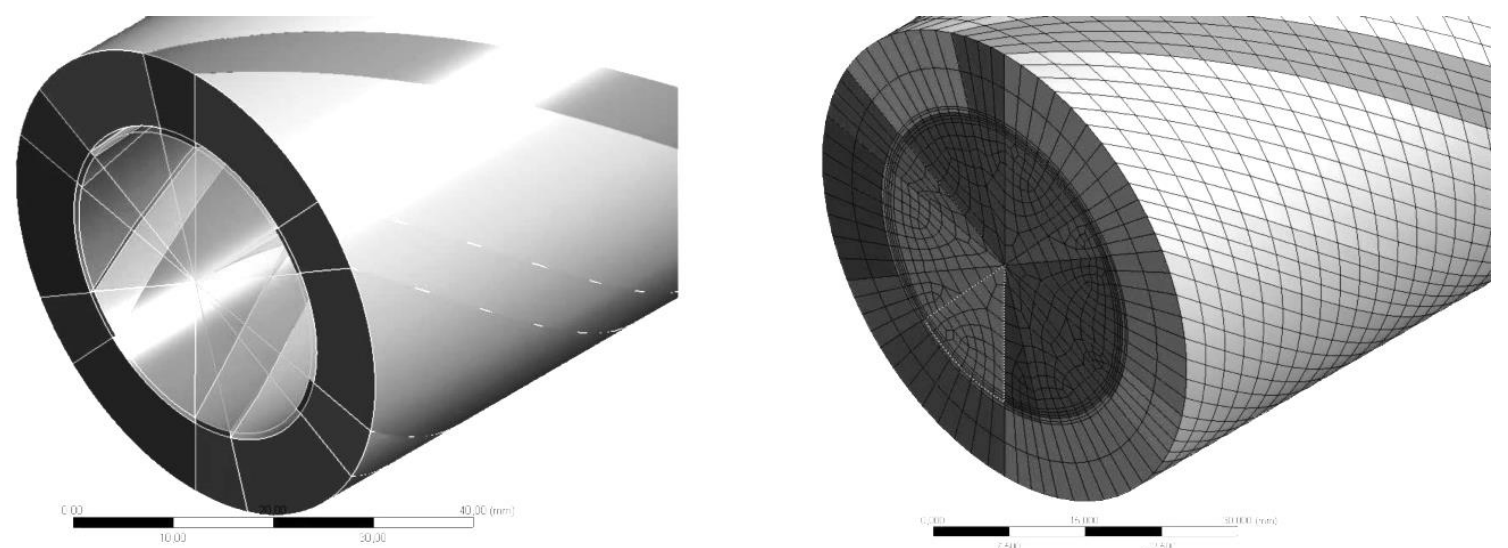

Fig. 5. Geometry sub-body division and generated mesh for tube a

After general settings and the selection of models, fluid and solid domains were determined. Also, the cell zone and boundary conditions were determined (Table 3). In this study, as a solution method, a coupled algorithm was chosen. This kind of algorithm is slow but has an advantage of solving the connection of different bodies (solid and fluid).

Table 3. Fluid and solid domain characteristics and boundary conditions

\begin{tabular}{|c|c|c|c|c|c|}
\hline Fluid & \multicolumn{2}{|c|}{ Water } & Solid & \multicolumn{2}{|c|}{$\begin{array}{c}\text { Stainless steel } \\
316 \mathrm{~L}\end{array}$} \\
\hline Density, $\rho_{f}$ & $\mathrm{~kg} / \mathrm{m}^{3}$ & 998.2 & Density, $\rho_{\mathrm{s}}$ & $\mathrm{kg} / \mathrm{m}^{3}$ & 8030 \\
\hline $\begin{array}{l}\text { Thermal } \\
\text { conductivity, } k_{f}\end{array}$ & $\mathrm{~W} /(\mathrm{m} \cdot \mathrm{K})$ & 0.6 & Thermal conductivity, $k_{s}$ & $\mathrm{~W} /(\mathrm{m} \cdot \mathrm{K})$ & 16.27 \\
\hline Specific heat, $c_{p, f}$ & $\mathrm{~J} /(\mathrm{kg} \cdot \mathrm{K})$ & 4182 & Specific heat, $c_{p, s}$ & $\mathrm{~J} /(\mathrm{kg} \cdot \mathrm{K})$ & 502.48 \\
\hline Dynamic viscosity, $\eta$ & $\mathrm{kg} /(\mathrm{m} \cdot \mathrm{s})$ & 0.001003 & & & \\
\hline Inlet temperature, $T$ & $\mathrm{~K}$ & 300 & Flow length, $L$ & $\mathrm{~m}$ & 2 \\
\hline Water mass flux, $G$ & $\mathrm{~kg} /\left(\mathrm{m}^{2} \cdot \mathrm{s}\right)$ & 600 & & & \\
\hline Heat flux, $\dot{q}$ & $\mathrm{~kW} / \mathrm{m}^{2}$ & 100 & & & \\
\hline
\end{tabular}

\section{RESULTS AND DISCUSSION}

The results obtained in this study show that there are visible differences between rifled and smooth tubes. The characteristic temperature and calculated average heat transfer coefficient are shown in Table 4. Presented values of heat transfer coefficient were calculated by Eq. (1) and are the average values for the considered tubes. The required heat fluxes and temperatures were taken from the $C F D$ Post. As expected, the average temperature of fluid and average temperature of solid in outflow is higher in rifled tubes. It is associated with greater heat exchange surfaces and swirl pattern of flow. As observed in CFD Post, the heat transfer coefficient significantly increases at the top of the ribs and has lower value in the intercostal surface. However, the average value of calculated heat transfer coefficient is higher in both smooth tubes. It is connected with approximately $20 \%$ smaller heat exchange surface. When the obtained heat transfer coefficient for rifled tubes will be referred to the same surface like on plain tubes, it will grow by approximately $20 \%$.

In Fig. 6 and Fig 7, the temperature distribution in rifled (a) and plain (b) tubes are presented. It can be observed, that the ribs change the temperature profiles in solid and fluid. Swirling patterns range are 
also distinctly visible. Those two phenomena are presented in Fig. 8a. The cross-section shows the influence of ribs on the temperature profile in a solid and fluid body.

Table 4. Temperatures and average heat transfer coefficient obtained from CFD modelling

\begin{tabular}{|c|c|c|c|c|c|c|c|c|}
\hline & \multicolumn{4}{|c|}{ Rifled tube } & \multicolumn{4}{|c|}{ Plain tube } \\
\hline & $T_{f a}$ & $T_{s a}$ & $T_{f a, \text { out }}$ & $h_{a}$ & $T_{f a}$ & $T_{s a}$ & $T_{f a, \text { out }}$ & $h_{a}$ \\
\hline Tube a & 308.68 & 391.66 & 315.73 & 3025.77 & 307.36 & 387.01 & 313.99 & 3188.70 \\
\hline Tube b & 307.84 & 371.88 & 314.35 & 3110.40 & 307.04 & 371.03 & 313.38 & 3239.29 \\
\hline
\end{tabular}

a)

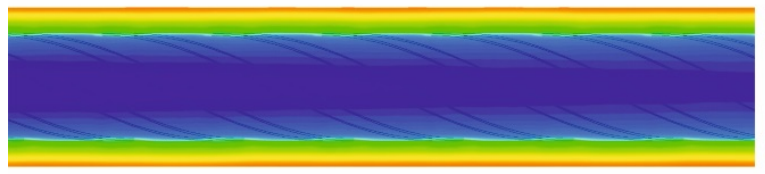

0.9

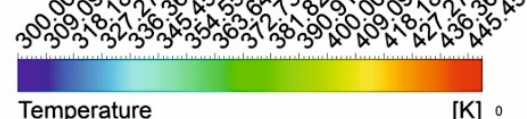

Temperature

$[\mathrm{K}]$

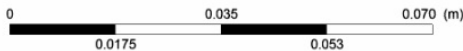

b)
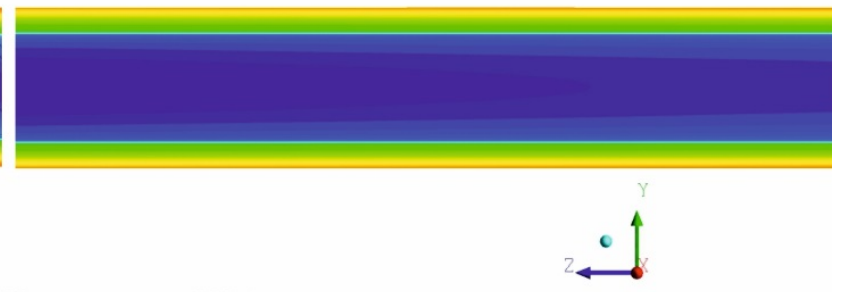

Fig. 6. Temperature comparison for tube 'a'; a) rifled, b) - plain

a)

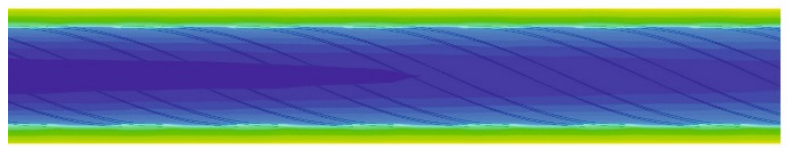

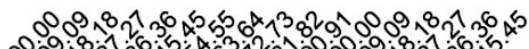

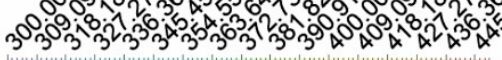

[K]

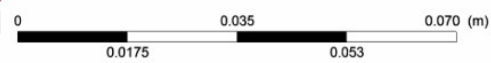

b)

Fig. 7. Temperature comparison for tube 'b'; a) rifled, b) plain

a)

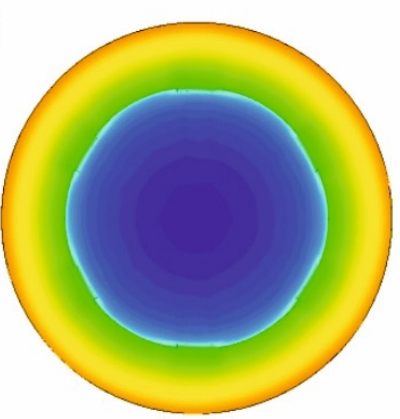

b)

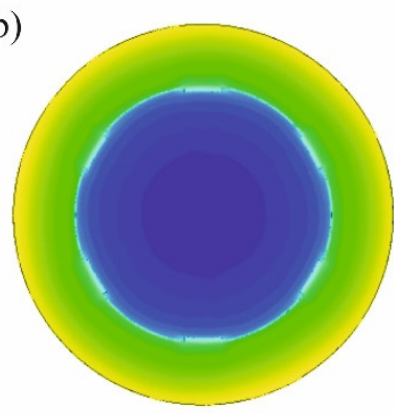

c)

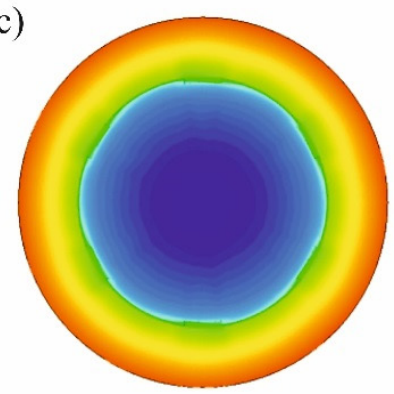

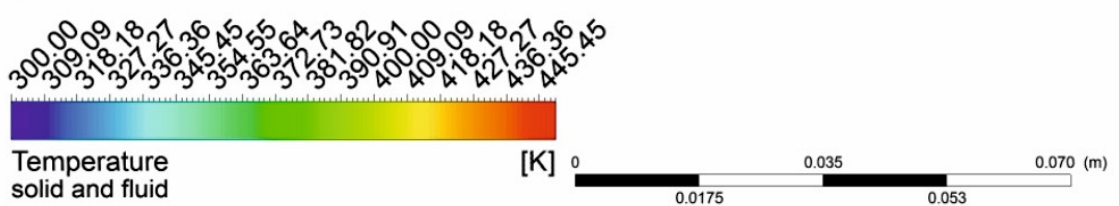

Fig. 8. Temperature comparison on outflow of tube $a$ and different turbulence models: a) SST, b) $k-\varepsilon, \mathrm{c}) k-\omega$ 
For the purposes of this paper, a grid independence study was conducted. For tube $a$, three types of mesh were prepared. The results are presented in Table 5. The standard mesh and mesh III vary in the number of inflation layers ( 8 in standard mesh and 5 for mesh III). The obtained temperatures are very similar. In the mesh II, the solid body in intercostal volume has less division nodes. That partitioning causes greater average solid temperature. Due to that fact, the solid body should be divided in more nodes to obtain more accurate results.

Table 5. Grid independence study

\begin{tabular}{|l|c|c|c|}
\hline & Standard mesh & Mesh II & Mesh III \\
\hline Cells & 897147 & 671553 & 817218 \\
\hline Nodes & 921536 & 692648 & 840752 \\
\hline$T_{f a}[\mathrm{~K}]$ & 308.68 & 308.62 & 308.60 \\
\hline$T_{s a}[\mathrm{~K}]$ & 391.66 & 395.72 & 391.07 \\
\hline$T_{f a, \text { out }}[\mathrm{K}]$ & 315.73 & 315.75 & 315.68 \\
\hline
\end{tabular}

In Fig. 8 the modelling results for different turbulence models are presented. Visible differences of temperature fields, especially in the solid body can be seen. Selected results are given in Table 6 . The differences of temperatures are the results of a variety of heat transfer coefficient calculations for 4equational transitional SST, and 2-equational $k$ - $\varepsilon$ and $k$ - $\omega$ turbulence models. $K$ - $\varepsilon$ model is appropriate for fully-developed turbulence flow. In this case, where mass-flux is about $600 \mathrm{~kg} /\left(\mathrm{m}^{2} \cdot \mathrm{s}\right)$, in intercostal space, laminar or transition flow may appear. The $k-\omega$ model demonstrates the opposite operation. For low Reynolds number zones, $k-\omega$ reproduces phenomena better, but there are problems in fullyturbulent zones at the top of ribs. Average results are obtained for transitional SST model, which combines the laminar, transitional and fully developed flow zones in two additional equations.

Table 6. Selected temperatures for different turbulence models in [K]

\begin{tabular}{|l|c|c|c|}
\hline & Transitional SST & $k-\varepsilon$ & $k-\omega$ \\
\hline$T_{f a}$ & 308.68 & 307.70 & 309.14 \\
\hline$T_{s a}$ & 391.66 & 375.20 & 400.09 \\
\hline$T_{f a, \text { out }}$ & 315.73 & 314.75 & 316.40 \\
\hline$h_{a} \mathrm{~W} /\left(\mathrm{m}^{2} \cdot \mathrm{K}\right)$ & 3188 & 4612 & 2579 \\
\hline
\end{tabular}

\section{CONCLUSIONS}

CFD modelling of heat transfer in internally helically ribbed tubes shows that enhanced inner surface clearly impacts on the heat transfer process. In the analysed cases, the medium outflow temperature difference of fluid in rifled tubes is by approximately $10 \%$ higher than that in plain tubes. For a short distance ( $2 \mathrm{~m}$ in length), there is a clear increase of heat transfer process. CFD modelling of a single phase flow shows, that the ribbed tubes' influence on the solid body temperature is not as noticeable as that in two phase flow with high steam quality. In the analysed cases, the medium tube temperature is greater than that for plain tubes. These differences are connected with the calculated medium heat transfer coefficient. For rifled and plain tubes, this quantity has similar values. The estimated heat transfer coefficient for rifled tubes will be higher by approx. $20 \%$ when it is referred to the same surface like in plain tubes. The selected turbulence model has a great impact on results. This study contains results obtained from the transitional SST, $k-\varepsilon$ and $k-\omega$ turbulence models, especially on the 
value of the heat transfer coefficient. It is connected to a better representation of phenomena for different flow structures. In the future, an experimental validation of CFD modelling heat transfer process in rifled tubes will be conducted.

\section{SYMBOLS}

$\begin{array}{ll}A & \text { area, } \mathrm{m}^{2} \\ b & \text { rib average width, } \mathrm{m} \\ c_{p} & \text { specific heat, } \mathrm{J} /(\mathrm{kg} \cdot \mathrm{K}) \\ d & \text { diameter, } \mathrm{m} \\ e & \text { rib height, } \mathrm{m} \\ g & \text { wall thickness, } \mathrm{m} \\ G & \text { mass flux, } \mathrm{kg} /\left(\mathrm{m}^{2} \cdot \mathrm{s}\right) \\ h & \text { heat transfer coefficient, } \mathrm{W} /\left(\mathrm{m}^{2} \cdot \mathrm{K}\right) \\ j & \text { Chilton-Colburne parameter, } \\ k & \text { thermal conductivity, } \mathrm{W} /(\mathrm{m} \cdot \mathrm{K}) \\ l & \text { length, } \mathrm{m} \\ N u & \text { Nusselt number, } N u=\left(l_{c} h\right) / k \\ p & \text { rib pitch, } \mathrm{m} \\ P r & \text { Prandtl number, } P r=\left(c_{p} \eta\right) / k \\ \dot{q} & \text { heat flux, } \mathrm{kW} / \mathrm{m}^{2} \\ R e & \text { Reynolds number, } R e=\left(v \rho l_{c}\right) / \eta \\ S t & \text { Stanton number, } S t=N u /(\mathrm{Pr} \operatorname{Re}) \\ T & \text { temperature, } \mathrm{K} \\ v & \text { velocity, } \mathrm{m} / \mathrm{s}\end{array}$

Greek symbols

$\begin{array}{ll}\alpha & \text { apex angle, } \\ \beta & \text { helix angle, } \\ \rho & \text { density, } \mathrm{kg} / \mathrm{m}^{3} \\ \eta & \text { dynamic viscosity, } \mathrm{kg} /(\mathrm{m} \cdot \mathrm{s}) \\ \text { Subscripts } & \\ a & \text { average } \\ b & \text { bulk } \\ c & \text { characteristic } \\ f & \text { fluid } \\ f a & \text { fluid volumetric average } \\ \text { out } & \text { outflow } \\ \text { s } & \text { solid } \\ \text { sa } & \text { solid volumetric average } \\ \text { w } & \text { wall }\end{array}$

\section{REFERENCES}

Ansys Inc. (www.ansys.com). 
Carnavos T., 1980. Heat transfer performance of internally finned tubes in turbulent flow. Heat Transfer Eng., 1, 32-37. DOI: $10.1080 / 01457638008939566$.

Dzierwa P., Taler D., Taler J., Trojan M., 2014. Optimum heating of thick wall pressure components of steam boilers. ASME 2014 Power Conference, Baltimore, United States, 28-31 July 2014. Paper No. POWER201432080. DOI: 10.1115/POWER2014-32080.

Dzierwa P. Taler J., 2015. Optimum heating of pressure vessels with holes. J. Pressure Vessel Technol., 137, 011202-011202-8. DOI: 10.1115/1.4027584.

Grądziel S., 2011. Determination of temperature and thermal stresses distribution in power boiler elements with use inverse heat conduction method. Arch. Thermodyn., 32, 191-200. DOI: 10.2478/v10173-011-0022-4.

Jensen M., Vlakancic A., 1999. Experimental investigation of turbulent heat transfer and fluid flow in internally finned tubes. Int. J. Heat Mass Transfer, 42, 1343-1351. DOI: 10.1016/S0017-9310(98)00243-9.

Majewski K., 2013. Concept of a measurement and test station for determining linear pressure drop and heat transfer coefficient of internally ribbed tubes. J. Power Technol., 93 (5), 340-346.

Modliński N.J., 2014. Computational modelling of a tangentially fired boiler with deposit formation phenomena. Chem. Process Eng., 35, 361-358. DOI: 10.2478/cpe-2014-0027.

Nowak-Woźny D., Moroń W., Urbanek B., Rybak W., 2013. Mineral matter transformation in oxy-fuel coal combustion. Chem. Process Eng., 34, 393-401. DOI: 10.2478/cpe-2013-0032.

Ocłoń P., Nowak M., Łopata S., 2014. Simplified numerical study of evaporation processes inside vertical tubes. J. Therm. Sci., 23, 177-186. DOI: 10.1007/s11630-014-0693-7.

Ocłoń P., Nowak M., Majewski K., 2013. Numerical simulation of water evaporation inside vertical circular tubes. 11th International Conference of Numerical Analysis and Applied Mathematics, Rhodes, Greece, 21-27 September 2013. AIP Conf. Proc., 1558, 2419-2422, DOI: 10.1063/1.4826029.

Pan J., Yang D., Dong Z., Zhu T., Bi Q., 2011. Experimental investigation on heat transfer characteristics of low mass flux rifled tube with upward flow. Int. J. Heat Mass Transfer, 54, 2952-2961. DOI: 10.1016/j.ijheatmasstransfer.2011.03.002.

Pilarczyk M., Cisek P., 2014. Possibility of coal power plants dynamics properties improvement in the context of increasing RES contribution in Polish power supply system (in Polish). Rynek Energii, 6 (115), 16-24.

Taler D., Trojan M., Taler J., 2014. Mathematical modeling of cross-flow tube heat exchangers with a complex flow arrangement. Heat Transfer Eng., 35, 1334-1343. DOI: 10.1080/01457632.2013.876874.

Taler J. (Ed.), 2011. Procesy cieplne i przeplywowe w dużych kottach energetycznych. PWN, Warszawa, 14-16.

Taler J., Duda P., Węglowski B., Zima W., Grądziel S., Sobota T., Taler D., 2009. Identification of local heat flux to membrane water-walls in steam boilers. Fuel, 88, 305-311. DOI: 10.1016/j.fuel.2008.08.011.

Trojan M., Taler D., Taler J., Dzierwa P., 2014. Modeling of superheater operation in a steam boiler. ASME 2014 Power Conference, Baltimore, United States, 28-31 July 2014. Paper No. POWER2014-32093. DOI: 10.1115/POWER2014-32093.

Wacławiak K., Kalisz S., 2014. Influence of selected parameters on ash particle trajectories when modelling deposition on superheater tubes in pulverised coal boilers using Fluent code. Chem. Process Eng., 35, 305-316. DOI: $10.2478 /$ cpe-2014-0023.

Webb R.L., Narayanamurthy R., Thors P., 2000. Heat transfer and friction characteristics of internal helical-rib roughness. J. Heat Transfer, 122, 134-142. DOI: 10.1115/1.521444.

Węglowski B., Ocłoń P., Majcher A., 2014. Monitoring of the stress state in the boiler drum using finite element method. Advanced Materials Research, 875-877, 1176-1182. DOI: 10.4028/www.scientific.net/AMR.875877.1176.

Zdaniuk G., Chamra L., Mago P., 2008. Experimental determination of heat transfer and friction in helicallyfinned tubes. Exp. Therm Fluid Sci., 32, 761-765. DOI: 10.1016/j.expthermflusci.2007.09.006.

Zima W., 2006. Simulation of dynamics of a boiler steam superheater with an attemperator. Proc. Inst. Mech. Eng., Part A: J. Power Energy, 220, 79-801. DOI: 10.1243/09576509JPE268.

Received 11 March 2015

Received in revised form 15 December 2015 Accepted 20 December 2015 